\title{
Relationships between Douglas fir seedling growth and levels of some soil and tissue nutrients
}

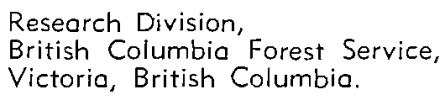

ODC 232.322: 160.21: 114.521.5.

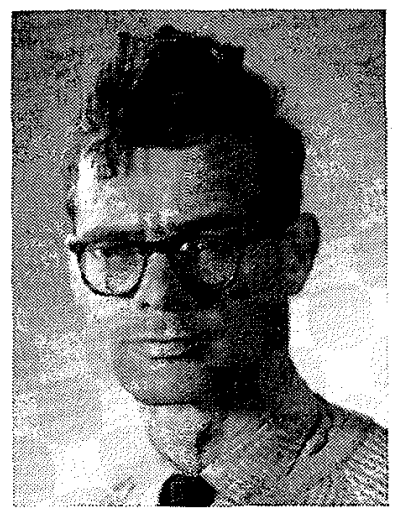

semblait dépendre de la concentration de $K$ dans le tissu. Augmenter le contenu de $\mathrm{Mg}$ du sol audessus de 1,5 m.e.q./100g. diminuait la croissance. Dans une serre $61 \%$ de variation du poids sec des plants s'expliquait en examinant la concentration de 6 éléments nutritifs, mais dans la pépinière $41 \%$ seulement de variation s'expliquait par 5 éléments nutritifs dans le tissu.

Douglas fir (Pseudotsuga menziesii (Mirb.) Franco) seedling grew poorly at Koksilah nursery (Duncan, B.C.) when the first sowings were made. Koksilah nursery soil is a Chemainus silt loam (Day et al, 1959) which had recently been converted from agricultural pasture. Growth was improved to a small extent by routine fertilizer dressings containing $40 \mathrm{lbs}$. N/acre, $60 \mathrm{lbs}$. P/acre and $30 \mathrm{lbs}$. $\mathrm{K} / \mathrm{acre}$.

To see whether first year soil and seedling tissue nutrient levels could be used for predicting Douglas fir seedling growth the relationship between seedling dry weight and nutrient levels was examined. A factorial fertilizer experiment was laid out at Koksilah nursery to create a range of nutrient levels. $P$ and $K$ fertilizers were used because chemical analysis of seedlings from this nursery had shown that tissue concentrations of $\mathrm{P}$ and $\mathrm{K}$ were relatively low (Bloomberg, 1965). Mg was included since improved growth of another western conifer, Sitka spruce (Picea sitchensis Carr.) has been obtained under similar nursery conditions with $\mathrm{Mg}$ fertilizer (Benzian, 1965). A greenhouse experiment was carried out to verify results of the nursery experi- 
ment under more controlled conditions and test whether any interaction between $\mathrm{P}$ and $\mathrm{Zn}$ occurred. $Z n$ was used because it has been shown to enhance response to $P$ in some agricultural crops (Burleson et al. 1961).

\section{Methods}

(1) Nursery experiment

A $3 \times 4$ factorial experiment, repeated on three blocks, was laid out so that each treatment plot had an area of ten square feet. A pre-treatment soil sample was taken from each plot on 12 May, 1965. Calcium superphosphate, potassium sulphate and magnesium sulphate fertilizers were applied on 17 May, 1965, to provide nutrients at four levels (Table 1). These fertilizers contain about $12 \%$, $18 \%$, and $27 \%$ S respectively. Douglas fir seed of local provenance was separated into three size fractions and medium-sized seed (100 seed weight $=1.037$ g.) was broadcast sown on 19 May, 1965, after two weeks stratification. A posttreatment soil sample was taken from each plot on 29 July, 1965. Soil samples were analysed for available $\mathrm{P}$ (using $0.03 \mathrm{~N} \mathrm{NH}_{4} \mathrm{~F}$ in $0.025 \mathrm{~N} \mathrm{HCL}$ ), exchangeable $\mathrm{K}$ by flame emission and $\mathrm{Mg}$ by atomic absorption spectrophotometry. Number of seedlings per square foot was determined in each plot on 8 July, 1965.

First season growth was measured on 20 seedlings dug from each plot on 27 and 28 October, 1965. Roots were washed and shoot lengths and total dry weights measured. These samples of seedlings were then milled in preparation for tissue analysis. $N$ concentration was determined by the Kjeldahl method, using a selenium catalyst. After perchloric acid digestion, $P$ concentration was determined using the vanadomolybdophosphoric method (Jackson, 1958), K concentration was determined by emission and $\mathrm{Ca}$ and $\mathrm{Mg}$ by atomic absorption spectophotometry.

At the beginning of the second growing season, on 27 April, 1966, a top dressing of ammonium nitrate was applied, at the rate of $40 \mathrm{lbs}$. N/acre, to all plots to reduce likelihood of serious $\mathrm{N}$ deficiency.

To evaluate growth after two years, ten whole seedlings were dug from each plot and the shoots of an additional 50 seedlings were removed by cutting them off at ground level on 3 and 4 October, 1966. Shoot and root weights were determined from these samples.

(2) Greenhouse experiment

Response of Douglas fir seedlings to $P, Z n$ and $N$ was tested on nursery soil in an illuminated and heated greenhouse. The experiment was of completely randomized design, repeated on two blocks. Calcium superphosphate was mixed into the top four inches of soil in $19 \mathrm{~cm}$. diameter cellulose fibre pots (3.9 litre capacity) prior to sowing with stratified seed on 11 October, 1966. Half the ammonium nitrate and zinc sulphate treatments were applied on 3 November, 1966, in $60 \mathrm{ml}$. of solution, ten days after germination was complete and the remainder 39 days after germination. Treatments were at the rates of 0,20 and $60 \mathrm{lbs} . \mathrm{P} / \mathrm{acre}, 0,1.25$ and $5 \mathrm{lbs}$. Zn/acre and 0 and $20 \mathrm{lbs}$. N/acre. Enough seed was sown to ensure that more than 20 seedlings germinated in each pot and the number was reduced to 20 per pot on 3 November, 1966. After 140 days' growth, shoot lengths and shoot and root weights were determined. Nutrient concentration of entire seedlings was analysed as described for the nursery experiment.

Results from both experiments were treated by analysis of variance and Duncan's new multiple range test was used for separating means.

\section{Results}

Nursery experiment

Fertilizer treatments in the nursery experiment were effective in creating a range of different levels of $\mathrm{P}, \mathrm{K}$ and $\mathrm{Mg}$ in the soil (Table 1).

Analysis of variance showed a significant inter-

Table 1. Fertilizer treatments and pre- and post-fertilizer treatment levels of available soil nutrients.

\begin{tabular}{|c|c|c|c|c|c|c|}
\hline \multirow[b]{2}{*}{$\begin{array}{l}\text { Treatment } \\
\text { Level }\end{array}$} & \multicolumn{2}{|c|}{$\mathrm{P}$} & \multicolumn{2}{|c|}{$\mathrm{K}$} & \multicolumn{2}{|c|}{$\mathrm{Mg}$} \\
\hline & $\begin{array}{c}\text { Treatment } \\
\text { (lbs. acre } \\
\text { of element) }\end{array}$ & $\begin{array}{l}\text { Available } \\
\text { p.p.m. in } \\
\text { soil }\end{array}$ & $\begin{array}{l}\text { Treatment } \\
\text { (lbs. acre } \\
\text { of element) }\end{array}$ & $\begin{array}{l}\text { Available } \\
\text { m.e.q. } / 100 \mathrm{~g} \\
\text { soil }\end{array}$ & $\begin{array}{l}\text { Treatment } \\
\text { (lbs. acre } \\
\text { of element) }\end{array}$ & $\begin{array}{l}\text { Available } \\
\text { m.e.q. } / 100 \mathrm{~g} \\
\text { soil }\end{array}$ \\
\hline & & \multicolumn{5}{|c|}{ Pre-treatment } \\
\hline & & 55.9 & & .0121 & & 1.28 \\
\hline & & \multicolumn{5}{|c|}{ Post-treatment: } \\
\hline 1 & 15 & $70.8 \mathrm{a}$ & 15 & $0.137 \mathrm{a}$ & 30 & $1.40 \mathrm{a}$ \\
\hline $\begin{array}{l}1 \\
2\end{array}$ & 30 & $81.8 \mathrm{a}$ & 30 & $0.169 \mathrm{~b}$ & 60 & $1.51 \mathrm{~b}$ \\
\hline 3 & 60 & $107.1 \mathrm{~b}$ & 60 & $0.212 \mathrm{c}$ & 120 & $1.75 \mathrm{c}$ \\
\hline 4 & 120 & $158.4 \mathrm{c}$ & 120 & $0.293 \mathrm{~d}$ & 240 & $2.09 \mathrm{~d}$ \\
\hline
\end{tabular}

*Values followed by the same letters are not significantly different at the 0.05 probability level. 
action between $\mathrm{P}$ and $\mathrm{Mg}$ treatments for first and second year growth data. This interaction is exemplified by one-year old shoot length (Fig. 1). At low $P$ levels shoot growth was essentially unaffected by increase in $\mathrm{Mg}$ but at high $\mathrm{P}$ levels shoot growth was depressed by increasing $\mathrm{Mg}$. After one year's growth, seedling dry weight had been significantly increased by $P$ fertilization, particularly at the heavier applications (Figure 2, Table 2). Differences in shoot weight were less by the end of the second year, though still substantial. The two higher $\mathrm{Mg}$ treatments depressed growth of one-year old seedlings. A similar situation existed in the second year, although only the $120 \mathrm{lb} . / \mathrm{ac} \mathrm{Mg}$ treatment clearly depressed two-year old shoot and root growth. Perhaps the average available soil $\mathrm{Mg}$ level of 1.5 m.e.q. $/ 100 \mathrm{~g}$. soil, resulting from the 30 lbs. Mg/acre treatment (Table 1), is the highest level suitable for good growth of Douglas fir. K treatment had no significant effect on seedling dry weight.

Treatments had no significant effect on numbers of seedlings per unit area (Table 2), so that responses observed were not due to differences in amount of competition between seedlings on the experimental plots.

Tissue analysis results showed that $P$ fertilization had the greatest effect in altering seedling nutrient levels since it significantly increased both tissue $P$ and $\mathrm{K}$ and decreased tissue $\mathrm{Ca}$ concentration (Table 3 ). $K$ treatments increased tissue $K$, while $\mathrm{Mg}$ treatments had no significant effect. Average tissue $\mathrm{Mg}$ levels, in order of increasing $\mathrm{Mg}$ fertilizer treatments, were: $0.327 \%, 0.313 \%, 0.316 \%$ and $0.337 \%$

Soil or tissue analysis variables could possibly have value in predicting seedling dry weight, so correlation analysis was carried out. Tissue $\mathrm{P}, \mathrm{K}$ and Mg concentrations were significantly correlated with measures of seedling dry weight in both years (Table 4). The highest correlation was calculated for dry weight and $K$, with dry weight and $P$ next highest. Co-efficients calculated between nutrient concentrations and first year dry weights were larger than those calculated with second year dry weights. First year seedling dry weight was significantly correlated with only soil $\mathrm{P}$ level. Inclusion of all tissue nutrients in a multiple correlation analysis accounted for some $41 \%$ of variation in one-year old seedling dry weight. $\mathrm{K}$ and $\mathrm{Mg}$ together explained some $39 \%$ of this variation. First year tissue nutrients showed little value for predicting two-year old shoot dry weight, and levels of soil $\mathrm{P}, \mathrm{K}$ and $\mathrm{Mg}$ showed little correlation with one-year old seedling dry weight.

$P$ treatments increased yield and also tissue $K$ concentration. Correlation between yield and tissue $K$ raised the possibility that effect of $P$ treatment on seedling yield was mediated through its effect on tissue K. Since, however, tissue $P$ and K concentrations were correlated $(r=0.75)$ their relationship to yield had to be considered together. Accordingly, simple regressions of seedling dry weight data were plotted against tissue $\mathrm{K}$ concentration for six ranges

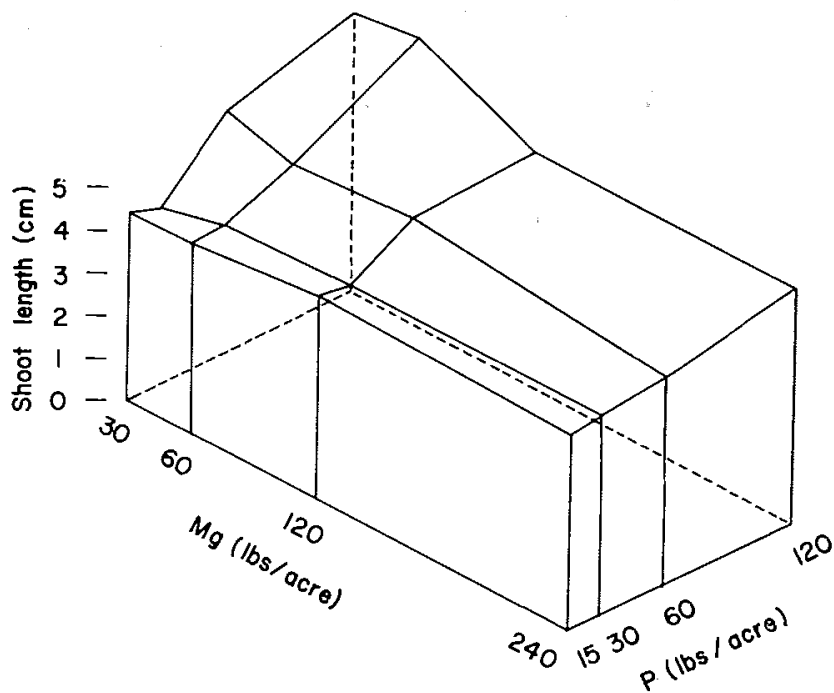

Fig. 1. Mean shoot length of one-year old Douglas fir seedlings for each $\mathrm{P}$ and $\mathrm{Mg}$ fertilizer combination.

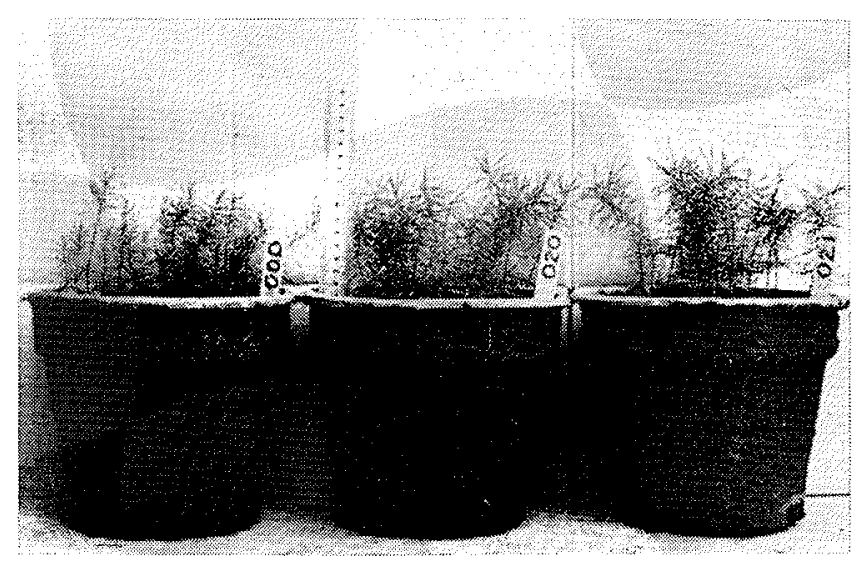

Fig. 2. Response of Douglos fir seedlings to $P$ treotment in greenhouse experiment. 000-control, 020-60 lbs. P/ac, 021-60 lbs. $\mathrm{P} / \mathrm{ac}$ and $1.25 \mathrm{lbs}$. $\mathrm{Zn} / \mathrm{ac}$. The scale shows $\mathrm{cm}$.

Table 2. Effect of $\mathrm{P}$ and $\mathrm{Mg}$ treatments on Douglas fir seedling dry weight, and seed bed density.

First year seed bed

O ne-year

Treatment old whole (lbs. acre) seedlings (g.)*

$\mathrm{P}$

P

$\begin{array}{rl}15 & .208 \mathrm{a} \\ 30 & .210 \mathrm{a} \\ 60 & .261 \mathrm{~b} \\ 120 & .329 \mathrm{c}\end{array}$

K

\begin{tabular}{|c|c|c|c|c|c|}
\hline 15 & $.244 \mathrm{a}$ & $2.53 \mathrm{a}$ & .68 & & 33 a \\
\hline 30 & $.254 \mathrm{a}$ & $2.68 \mathrm{a}$ & .72 & a & $33 \mathrm{a}$ \\
\hline 60 & $.250 \mathrm{a}$ & $2.54 \mathrm{a}$ & .69 & a & 35 \\
\hline 120 & $.262 \mathrm{a}$ & $2.53 \mathrm{a}$ & .66 & a & 34 \\
\hline 30 & $.268 \mathrm{a}$ & $2.60 \mathrm{a} \mathrm{b}$ & .74 & a & \\
\hline 60 & $.268 \mathrm{a}$ & $2.73 \mathrm{a}$ & .70 & $a b$ & 34 \\
\hline 120 & $.244 \mathrm{a} \mathrm{b}$ & $2.43 \mathrm{~b}$ & .59 & $\mathrm{~b}$ & 33 \\
\hline 240 & $.228 \mathrm{~b}$ & $2.50 \mathrm{a} \mathrm{b}$ & .71 & a & 35 \\
\hline
\end{tabular}

*Values followed by the same letters are not significantly different at the 0.05 probability level. 
of tissue $\mathrm{P}$ concentration. The six ranges of $\mathrm{P}$ were obtained by arranging all data in ascending order of $P$ concentration and then dividing the observations into six equal groups (Table 5). Dry weight and tissue $K$ concentration were significantly related in range $5(p=0.01)$ and range $6(p=0.05)$. Evidently increases in tissue $K$ concentration had very little relation to yield until a tissue $\mathrm{P}$ concentration of $0.17 \%$ and a tissue $\mathrm{K}$ concentration of $0.56 \%$, were exceeded.

\section{Greenhouse experiment}

Results from the greenhouse pot test confirmed that $P$ additions to Koksilah nursery soil could improve growth. The data suggested that shoot length and seedling dry weight were markedly improved only when seedling tissue $P$ concentration was substantially above $0.18 \%$ (Table 6 ). Neither the low $\mathrm{N}$ treatment nor $\mathrm{Zn}$ treatment had any significant effect on seedling growth, although tissue $\mathrm{Zn}$ concentration was negatively correlated with seedling dry weight (Table 4). Tissue $\mathrm{P}$ concentration accounted for $17 \%$ of the variation in yield. Combination of $\mathrm{Mg}$, which was negatively related to dry weight, with $\mathrm{Ca}$ and $\mathrm{P}$ concentrations accounted for $52 \%$ of the variation in yield and all nutrients combined accounted for $61 \%$ of the variation in yield. In contrast to the nursery experiment, there was scarcely any relationship between tissue $K$ concentration and seedling dry weight. This was probably because the level of tissue $K$ was less variable and higher (mean value $0.903 \%$ ), than in the nursery experiment.

\section{Discussion}

These experiments show that Douglas fir seedling growth may be increased by superphosphate fertilizer supplying up to $120 \mathrm{lbs}$. P/acre on Koksilah nursery soil. The relationship between soil $\mathrm{P}$ level and Douglas fir growth suggests that response to superphosphate can be expected until the $\mathrm{P}$ level in this soil approaches at least $150 \mathrm{ppm}$. On the other hand, increasing exchangeable $\mathrm{Mg}$ above 1.5 m.e.q. $/ 100 \mathrm{~g}$. soil is likely to reduce Douglas fir seedling growth.

In both experiments $P$ treatment was more effective in altering seedling nutrient concentration than other treatments. $K$ concentration of nursery seedling tissue was increased by $P$ fertilization and multiple regression analysis suggested that seedling dry weight was more closely related to tissue

Table 3. Effect of $\mathrm{P}$ and $\mathrm{K}$ fertilizer treatments on tissue nutrient concentrations of one-year old Douglas fir seedlings

\begin{tabular}{|c|c|c|c|c|c|}
\hline \multirow{2}{*}{$\begin{array}{l}\mathrm{P} \\
\text { treatment } \\
\text { lbs. acre }\end{array}$} & \multirow[b]{2}{*}{$\% \mathrm{P}^{*}$} & & \multicolumn{3}{|c|}{$\underset{\text { treatment }}{\mathrm{K}}$} \\
\hline & & $\% \mathrm{~K}^{*}$ & $\% \mathrm{Ca}^{*}$ & lbs acre & $\% \mathrm{~K}^{*}$ \\
\hline 15 & $0.135 \mathrm{a} \mathrm{b}$ & $0.528 \mathrm{a}$ & $0.199 \mathrm{a}$ & 15 & $0.555 \mathrm{a}$ \\
\hline 30 & $0.128 \mathrm{a}$ & $0.571 \mathrm{~b}$ & $0.214 \mathrm{a}$ & 30 & $0.578 \mathrm{a}$ \\
\hline 60 & $0.154 \mathrm{~b} \mathrm{c}$ & $0.618 \mathrm{c}$ & $0.166 \mathrm{~b}$ & 60 & $0.614 \mathrm{~b}$ \\
\hline 120 & $0.162 \mathrm{c}$ & $0.646 \mathrm{c}$ & $0.177 \mathrm{~b}$ & 120 & $0.616 \mathrm{~b}$ \\
\hline
\end{tabular}

*Values followed by the same letters are not significantly different at the 0.05 level of probability.
Table 4. Coefficients for simple and multiple correlation of seedling dry weight with soil and tissue nutrient levels.

\begin{tabular}{|c|c|c|c|}
\hline \multirow[t]{3}{*}{$\begin{array}{l}\text { Independent } \\
\text { variables }\end{array}$} & \multicolumn{3}{|c|}{ Dependent variables } \\
\hline & \multicolumn{2}{|c|}{ Nursery Experiment } & Greenhouse Experiment \\
\hline & $\begin{array}{l}\text { Year } 1 \text { total } \\
\text { dry weight }\end{array}$ & $\begin{array}{l}\text { Year } 2 \text { shoot } \\
\text { dry weight }\end{array}$ & $\begin{array}{l}\text { Total } \\
\text { dry weight }\end{array}$ \\
\hline \multicolumn{4}{|c|}{ Simple correlation coefficients } \\
\hline Tissue N & .104 & $.209 * *$ & -.313 \\
\hline Tissue $\mathrm{P}$ & $.454^{* ; *}$ & $.290^{* * *}$ & 416 \\
\hline Tissue $\mathrm{K}$ & $.555^{* *}$ & $.362^{* *}$ & .095 \\
\hline Tissue $\mathrm{Ca}$ & $-.155^{*}$ & -.121 & .135 \\
\hline Tissue $\mathrm{Mg}$ & $.352^{* * *}$ & $.238^{* *}$ & -.021 \\
\hline Tissue Zn & - & - & $-.403^{*}$ \\
\hline \multicolumn{4}{|c|}{ Multiple correlation coefficients } \\
\hline & $.644^{* *}$ & $.437^{* *}$ & $.781^{* ;}$ \\
\hline \multicolumn{4}{|c|}{ Simple correlation coefficients } \\
\hline Soil $P$ & $.440 * *$ & - & - \\
\hline $\mathrm{K}$ & .087 & - & - \\
\hline $\mathrm{Mg}$ & -029 & $\ldots$ & $\ldots$ \\
\hline \multicolumn{4}{|c|}{ Multiple correlation coefficients } \\
\hline & $.446^{* *}$ & - & - \\
\hline
\end{tabular}

${ }^{*}$ significant at $5 \%$ level of probability

*:* significant at $1 \%$ level of probability

Table ${ }^{-5}$. $\mathrm{P}$ and $\mathrm{K}$ tissue analysis by six ranges of $\mathrm{P}$ level, and regression constants for seedling dry weight against $K$ in each range.

\begin{tabular}{|c|c|c|c|c|}
\hline \multirow[t]{2}{*}{$\begin{array}{c}\text { Range } \\
\text { (32 observations } \\
\text { per range) }\end{array}$} & \multirow[t]{2}{*}{$\begin{array}{c}\text { Range of } \\
\text { seedling } \\
\text { P\% }\end{array}$} & \multirow[t]{2}{*}{$\begin{array}{c}\text { Range of } \\
\text { seedling } \\
\mathrm{K} \%\end{array}$} & \multicolumn{2}{|c|}{$\begin{array}{l}\text { Regression of seedling } \\
\text { dry weight against } \\
\text { tissue } K\end{array}$} \\
\hline & & & $\begin{array}{l}\text { Regression } \\
\text { coefficients }\end{array}$ & $\begin{array}{l}\text { Simple } \\
\text { correlation } \\
\text { coefficient }\end{array}$ \\
\hline 1 & $.070-.089$ & $.406-.656$ & -.119 & .245 \\
\hline 2 & $.089-.109$ & $.402-.635$ & -.090 & .148 \\
\hline 3 & $.109-.130$ & $.411-.611$ & .281 & .276 \\
\hline 4 & $.130-.164$ & $.421-.755$ & .328 & .352 \\
\hline 5 & $.166-.199$ & $.558-.786$ & 1.568 & $.663^{* * *}$ \\
\hline 6 & $.200-.316$ & $.597-.980$ & .634 & $.437^{*}$ \\
\hline
\end{tabular}

*significant at $5 \%$ level of probability

**significant at $1 \%$ level of probability

Table 6. Effect of treatment on Douglas fir seedling shoot length, total weight and $\mathrm{P}$ concentration in greenhouse experiment)

\begin{tabular}{cccc}
\hline $\begin{array}{l}\text { P treatment } \\
\text { (lbs. acre) }\end{array}$ & $\begin{array}{c}\text { Shoot length } \\
(\mathrm{cm} .)^{*}\end{array}$ & $\begin{array}{c}\text { Total } \\
\text { seedling dry } \\
\text { weight (g.) }\end{array}$ & $\begin{array}{c}\text { Tissue } \\
\mathrm{P} \mathrm{\%} \%^{*}\end{array}$ \\
0 & $8.74 \mathrm{a}$ & $.105 \mathrm{a}$ & $.181 \mathrm{a}$ \\
20 & $9.23 \mathrm{a}$ & $.112 \mathrm{a}$ & $.169 \mathrm{a}$ \\
60 & $10.93 \mathrm{~b}$ & $.144 \mathrm{~b}$ & $.259 \mathrm{~b}$ \\
\hline
\end{tabular}

*Values followed by the same letters are not significantly different at the 0.05 level of frobability. 
$\mathrm{K}$ than to $\mathrm{P}$ concentration. It seemed, however, that tissue $\mathrm{P}$ concentration above about $0.17 \%$ was necessary before there was a relationship between tissue $K$ and dry weight. Possibly growth was severely limited by lack of tissue $\mathrm{P}$ below $0.17 \% \mathrm{P}$ but above this concentration, tissue $K$ was limiting growth. Data from the greenhouse experiment were also consistent with the view that seedling growth was very limited below a tissue $P$ concentration of about $0.18 \%$. This generally agrees with results obtained by Themlitz (1958) who found that healthy Douglas fir seedlings contained $0.20-0.22 \% \mathrm{P}$, whereas seedlings suffering from excessive $\mathrm{Ca}$ fertilization contained $0.12-0.16 \% \mathrm{P}$.

Only at the two higher $\mathrm{P}$ treatment levels was the adverse effect of $\mathrm{Mg}$ manifest. Lack of interaction between $\mathrm{P}$ and $\mathrm{Mg}$ treatments in the 15 and 30 Ibs./acre nursery treatments may have been due to the low level of $P$ limiting growth so severely that $\mathrm{Mg}$ treatment had no further adverse effect.

\section{References}

BENZIAN, B. 1965. Experiments on nutrition problems in forest nurseries. Volume I. For. Comm. Bull. 37. London H.M.S.O. pp. 251.

BLOOMBERG, W. J. 1965. Severe mineral deficiencies in Douglas-fir feedlings in a newly developed forest nurs. ery Bi-monthly progress report 21 (5):4. Can. Dep. For., Ottawa.

BURLESON, C. A., A. D. DACUS and C. J. GERARD. 1961. The effect of phosphorus fertilization on the zinc nutri-
Higher correlation of tissue nutrient concentration with seedling dry weight in the greenhouse experiment, compared to the nursery experiment, may have been due to increased uniformity of unmeasured environment factors, such as water supply, in the greenhouse.

Only $19 \%$ of two-year old shoot dry weight variation was accounted for by first year tissue nutrient concentration. Total seedling dry weight might have revealed a closer relationship with nutrient concentration but available results imply that mineral nutrient status of one-year old seedlings is of little relevance to the dry weight of two-year old seedlings. Apparently one-year old mineral nutrient concentration would be of little value in predicting twoyear old shoot growth.

\section{Acknowledgements}

The author acknowledge statistical guidance from Mr. A. R. Froser, computing aid from Mr. M. Kovots and technical ossistance from Mr. K. H. Austin and M. B. Balderston, all of the B.C. Forest Service Research Division.

tion of several irrigated crops. Soil Sci. Soc. Amer. Proc., 25:365-368.

DAY, J. H. L. FARSTAD and D. G. LAIRD 1959. Soil survey of south-east Vancouver Island and Gulf Islands, British Columbia. Report No. 6, B. C. Soil Survey.

JACKSON, M. L. 1958. Soil chemical analysis. Constable and Co. Ltd., London, pp. 498

THEMLITZ, R. 1958. Zur Phosphorsäuredungung junger Forstpflanzen. Phosphorsäure, 18:214-219.

\section{New Members}

\section{ACTIVE}

\author{
P. J. Adossides, \\ Commonwealth Forestry \\ Institute, \\ South Parks Rd., \\ Oxford, England
}

S. Yorgandjiolou, 475 Pembroke St. W., Pembroke, Ont.
D. L. Buell,

Wagner Woodlands \& Co., Lyme, Hampshire, 03768

Clare A. Hewson, Dept. of Fisheries \& Forestry Box 4000, Fredericton, N.B.

H. R. Glascock Jr., 7000 River Oaks Drive, McLean, Virginia 22101

George Brewster, Lindbrook, Beaver County, Alta.
C. J. Highsted, 1150 Cluculz Ave., Prince George, B.C.

T. G. Budreo, Meadow Lake, Sask.

T. W. Cross, 345 - 27th St. W., Prince Albert, Sask.

\section{STUDENT}

Ian R. Methven, Petawawa Forest Exp. Station, Chalk River, Ont. 